\title{
Assessment of different methods of bovine oocytes collection, maturation and Invitro fertilization of abattoir specimens
}

\author{
W.M. Saleh \\ Department of Surgery and Obstetric, College of Veterinary Medicine, University of Baghdad, Baghdad, Iraq
}

(Received April 14, 2017; Accepted May 13, 2017)

\begin{abstract}
The aim of this study is designed to evaluate the best methods for cow oocytes collection from abattoir specimens which is the cheapest, easily obtained and bulky number. Forty five fresh cow genitalia specimens and testicle were collected directly after slaughter from Al-Shoáalla abattoir north-west of Baghdad the capital early morning, transported in cool box under (4-8) ${ }^{\circ} \mathrm{C}$ to the laboratory of theriogenology in the college of veterinary medicine/Baghdad University during the period from November 2016 to February 2017. Ovaries were separated from the surrounding tissues, washed thoroughly with dis. water repeatedly, then with normal saline and finally with MEM medium containing Antibiotics and Nystatin for contaminant elimination. Oocytes were collected with four methods aspiration, slashing, slicing after aspiration and slicing. The result showed that; the collected oocytes were 55, 68, 87 and 106 oocytes respectively; slicing methods yield more oocytes count. Period of time between slaughtering and samples processing significantly affect oocytes collected percentage and quality, periods as 2, 6, 12 and 24 hours yield $75 \%, 68 \%, 61 \%$ and $55 \%$ oocytes counts of good, fair, poor to aged and bad quality oocytes respectively. Two hours period yield an elevated oocytes count with good quality. Maturation index of oocytes according to the type of collected methods showed 44, 37, 39 and 42 with 12, 8, 6 and 6 good oocyte quality for the four methods respectively. In conclusion slicing methods yield more oocytes count with a moderate quality and embryos production while aspiration methods yield a moderate oocytes count with an elevated quality and good embryos production.
\end{abstract}

Keywords: Oocytes, Aspiration, Slashing, Slicing, Embryo

Available online at http://www.vetmedmosul.org/ijvs

$$
\begin{aligned}
& \text { تقييم طرقي مختلفةٍ لجمع بويضات الابقار من عينات المجزرة، انضاجها والإخصاب خارج الجسم } \\
& \text { وافر مهدي صالح } \\
& \text { فرع الجر احة و التوليد، كلية الطب البيطري، جامعة بغداد، بغداد، العراق }
\end{aligned}
$$

ان الهدف من هذه الدراسة هو تقييم أفضل الطرق لجمع بويضات الابقار من عينات المسلخ و التي هي الارخص قيمةً، سهلة الحصول

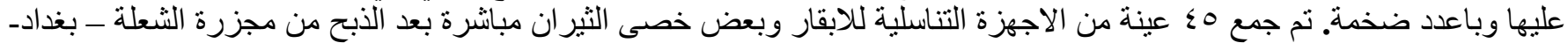

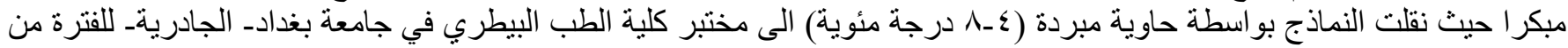

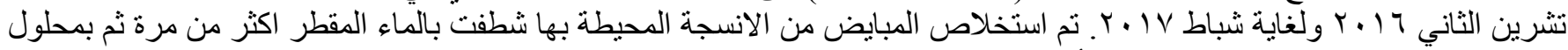

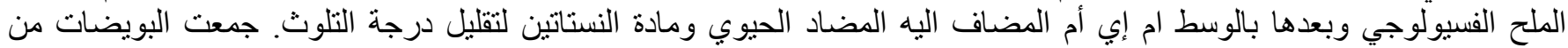

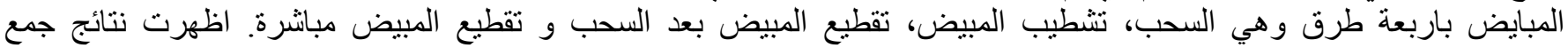

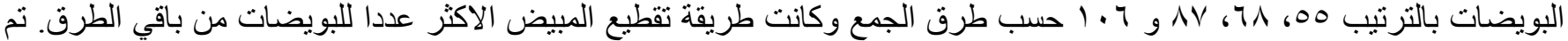

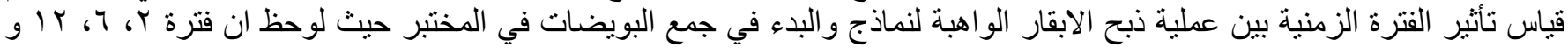

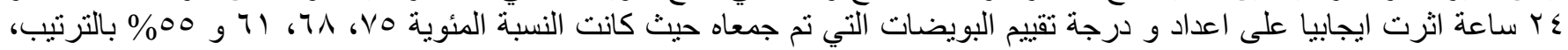
كانت فترة الساعتين بين النحر والمختبر هي الاكثر انتاجا للبويضات ذوات ذات التقييم الجيد، وكان المستوى القياسي لانضاج البويضات 


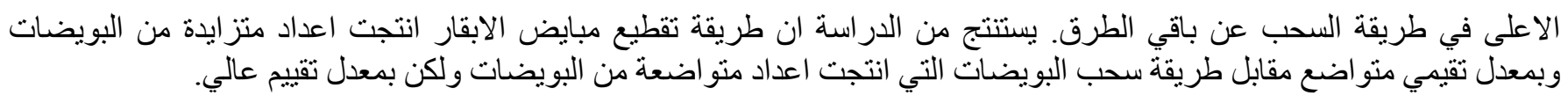

\section{Introduction}

Since the number of endangered species is increasing, it is therefore mandatory to develop an effective methodology for their germ cells to be harvested after death and then preserved with acceptable quality (1).

Assisted reproductive technologies such as ovarian hyper-stimulation (Superovulation), collection of immature oocytes, in vitro maturation (IVM), artificial insemination (AI), in vitro fertilization (IVF), and embryo transfer (ET) have been introduced to increase the number of offspring from selected females, and to reduce the generation intervals in Bovidae spp. (2). Ovaries obtained from the slaughterhouse constitute an economical source of oocytes. This allows for large scale and economical production of embryos (3).

There is a discrepancy in the reproductive performance between different cattle breeds. Using abattoir-derived ovaries and data base information we studied the effects of breed on in vitro fertilization and early embryo development (4).

Since the seventieth of the last century when Artificial Insemination (AI) technology had been introduced in Iraq as a tool for progeny improvement between the less genetically factors natively breed with highly produced foreign breed, the produced cross breed possessed a considerably moderated to high producing progeny and when those progeny accidentally injured to death or loss its ability to reproduce they would sent to the abattoirs, those genitalia (ovaries) still gained their genetic factors which act as very good sources for those techniques that introduced into the progeny improvement programs (5).

Over the last 10-15 years, after a dramatic development of cellular biology, a lot of research efforts have been moved towards the implementation of embryo technologies involving multiple ovulation and embryo transfer (MOET), in vitro production (IVP) of embryos, cloning and transgenesis to transfer a targeted number of embryos, and among all, IVP of embryos has become a routine method of producing embryos from abattoir derived ovaries with minimal cost (6).

The success target in embryo transfer technique mostly depend on embryo production from slaughter house ovaries, and these steps involved collection and evaluation (grading) the collected oocytes, invitro oocyte maturation (IVM), invitro fertilization (IVF) and invitro embryo production (IVP) to the final step which is the zygote development which is demonstrated for further cleavage (morulla and blastocyst) until transferring to synchronized recipient (7).
Oocytes can be recovered in relatively large numbers from abattoir ovaries, the oocytes frequently have reduced development potential when compared to in vivo matured or immature oocytes collected after gonadotropin treatment (8).

(9) compared between two methods in oocytes collection from abattoir samples, the ovum-pick up (OPU) and the aspiration one in related to oocytes number, quality and invitro maturation index (IVM), those parameters were more positively affected in the aspiration method than the other one. (10) reported that a significantly higher oocyte recovery rate was obtained from the ovaries without CL collected from abattoir samples, ovaries with CL yield less oocyte upon collection; large follicles are of moderate size in ovaries bearing CL.

(11) showed that, the percentages of oocytes collected from ovaries bearing CL were lower $(p<0.001)$ than those obtained from ovaries not bearing a CL, the negative effect of $\mathrm{CL}$ on the developmental competence of bovine oocyte depends on the follicle size in which it affected the oocytes number.

(12) showed that; the results obtained with 8-cell delayed embryos indicated that transcriptional activity was determined by the interval after fertilization rather than the number of cell cycles.

(13) evaluated three oocytes collected methods form ovaries directly harvested from abattoir specimens, the slashing, aspiration and the slicing methods, their results showed that the slicing methods away from the degree of development yield an elevated oocytes number than the other two methods.

(14) described three oocytes collection methods, the ovarian cutting, oocytes aspiration and ovarian slicing methods invitro using abattoirs samples, his results showed that the slicing methods yield more Oocytes number than the other two.

The objective of this study is well designed to use an abattoir samples for oocytes collection and invitro embryos production (IVP) and to evaluate the more suitable method that under Iraqi circumstances may gave us the perfect result we need.

\section{Materials and methods}

The forty five abattoir cow genitalia were collected directly after slaughtering at Al-Shoáalla abattoir, northwest of Baghdad the capital early morning kept in cool box under $(4-8)^{\circ} \mathrm{C}$ as described by (15) transported to the laboratory of Theriogenology in the College of Veterinary 
Medicine, Baghdad University during the period from November 2016 to February 2017.

Ovarian samples were prepared as described by (14), firmly and smoothly separated from surrounded tissues by clean scissor washed more than one time with dis. water then with normal saline, kept in becker containing MEM with antibiotic solution for settlement at room temperature (RT) for 5-10 minutes before processing, Samples were divided for three groups as fifteen ovaries per one group, for each group one oocytes collection method was conducted under aseptic condition inside the well disinfected hood cabinet for minimizing the air pollution or contaminated surroundings that might interfere with the final results, ovarian samples of the fourth collected method are the same ovarian number of the aspiration method, in which they conducted for this type of Oocytes collection after aspiration was performed previously.

\section{Oocytes collection}

Oocytes were collected by the following methods:

\section{Oocytes aspiration}

15 collected ovaries bearing big size follicles subjected to aspiration using 18 gauge needle connected to $3 \mathrm{ml}$ plastic syringe containing $1 \mathrm{ml}$ MEM medium collected oocytes were kept in a glass Petri-dishes containing 5-6 ml MEM for further examination as described by (16). Number of collected oocytes was recorded after grading; the only fair and good quality oocytes were subjected to the IVM and further IVF steps.

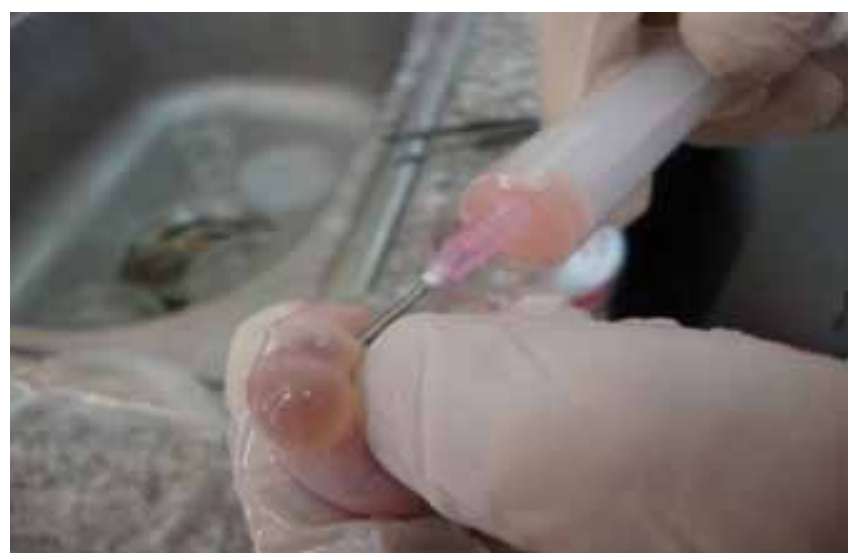

Fig. 1: Aspiration method for Oocytes collection using gauge 18 needle connected to plastic syringe containing collected medium.

\section{Ovarian slashing for Oocytes collection}

15 collected ovaries were subjected to slashing methods as described by (17). Ovarian sample after detached smoothly and firmly from surrounding tissues and fat were washed with dis. water and normal saline then suspended in becker containing MEM medium with antifungal and antibiotic preparations at (RT), each one entire organ would be grasped or snatched well by artery forceps slightly over the solution preparation inside the becker, by a fine surgical blade the snatched organ would be firmly clipped mainly over the follicles many times in which the follicular fluid would be dropped in the medium below with involving oocytes, then the whole entire organ was stripped and sheared transversally by the blade to be sure that all the content will be dropped down in the medium. The collected medium was subjected to Oocytes detection, collection, counting and grading for the second step of maturation, all result will be recorded.

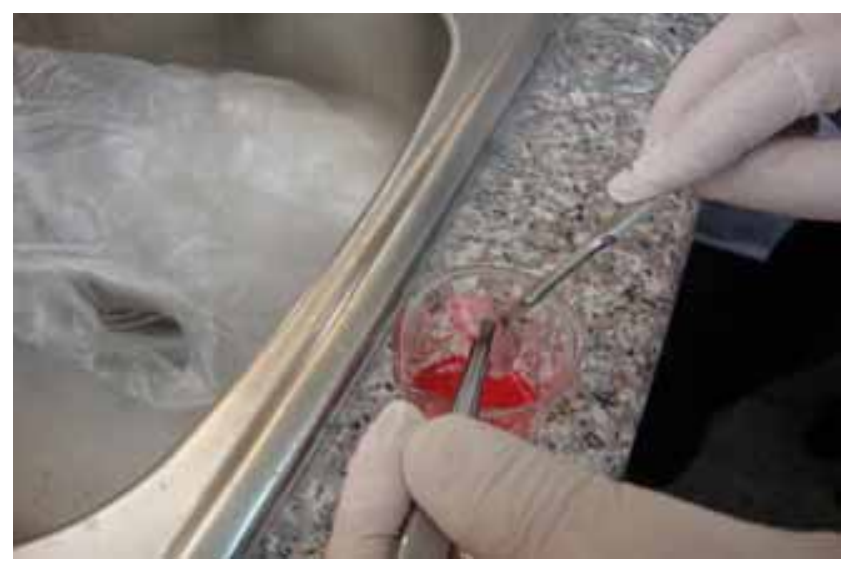

Fig. 2: Slashing methods for Oocytes collection using surgical blade suspended over Becker containing some of collected medium.

\section{Ovarian slicing for Oocytes collection}

15 collected ovaries were subjected to slicing method as described by (18). Ovarian samples after detached smoothly and firmly from surrounding tissues and fat were washed with dis. water and normal saline then suspended in Becker containing MEM medium with antifungal and antibiotic preparations at (RT). The ovaries were held firmly with the help of forceps in a sterile glass Petri dish containing $2 \mathrm{ml}$ of above medium, then sliced into possible thin sections with a surgical blade, MEM medium containing oocytes were placed in Petri dish and examined grading, all results will be recorded.

\section{Ovarian aspiration plus slicing technique for Oocytes collection}

The 15 collected ovaries were previously subjected for aspiration method, were tried again to further slicing to obtain more oocytes count if there were be a residual oocytes (post aspiration slicing) according to (19). Then number of oocytes collected from these additional techniques was counted, graded and recorded. 


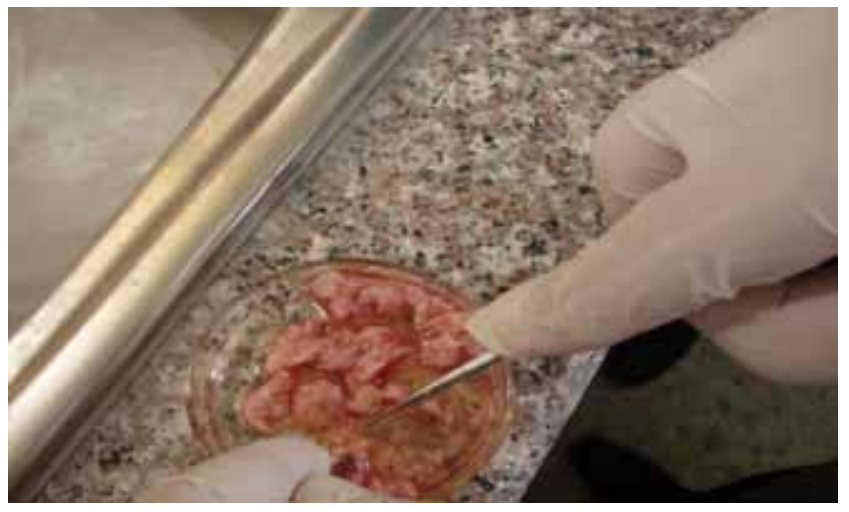

Fig. 3: Slicing method for Oocytes collection

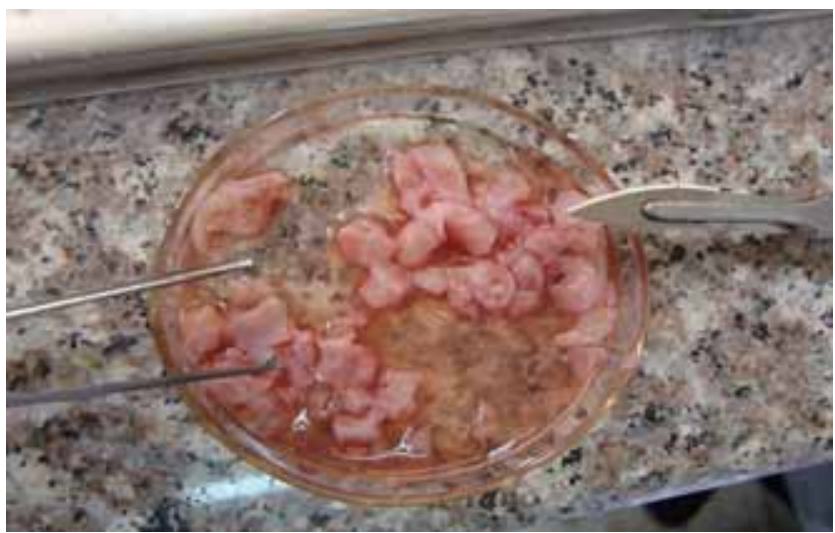

Fig. 4: Slicing after aspiration method for Oocytes collection.

\section{Oocytes evaluation}

Collected oocytes by the four methods were subjected to quality evaluation as mentioned by (20) in regarding to the arrangement of cumulus cell surrounding oocytes as well as status of cytoplasm as: Good grade: when the oocytes with many layers of cumulus cells and a transparent, homogenous and uniform cytoplasm. Fair grade: when the oocytes with less compact cumulus cells with transparent, less homogenous (some granules may found) and uniform. Poor grade: when the oocytes with mild or absent cumulus (denuded) with dark and granular cytoplasm.

After grading and quality evaluation of the collected oocytes, the only good and fair grades oocytes were subjected to the process of in vitro maturation (IVM), oocytes after grading were moved to another Petri-dishes containing maturation medium as prepared by (21), by aspiration with an automatic micropipette, re-examining the dishes after these ova transport, and to be sure that all selective ova were transport. Ova were grading and counting and recorded will be ready for maturation process, (Fig. 5).

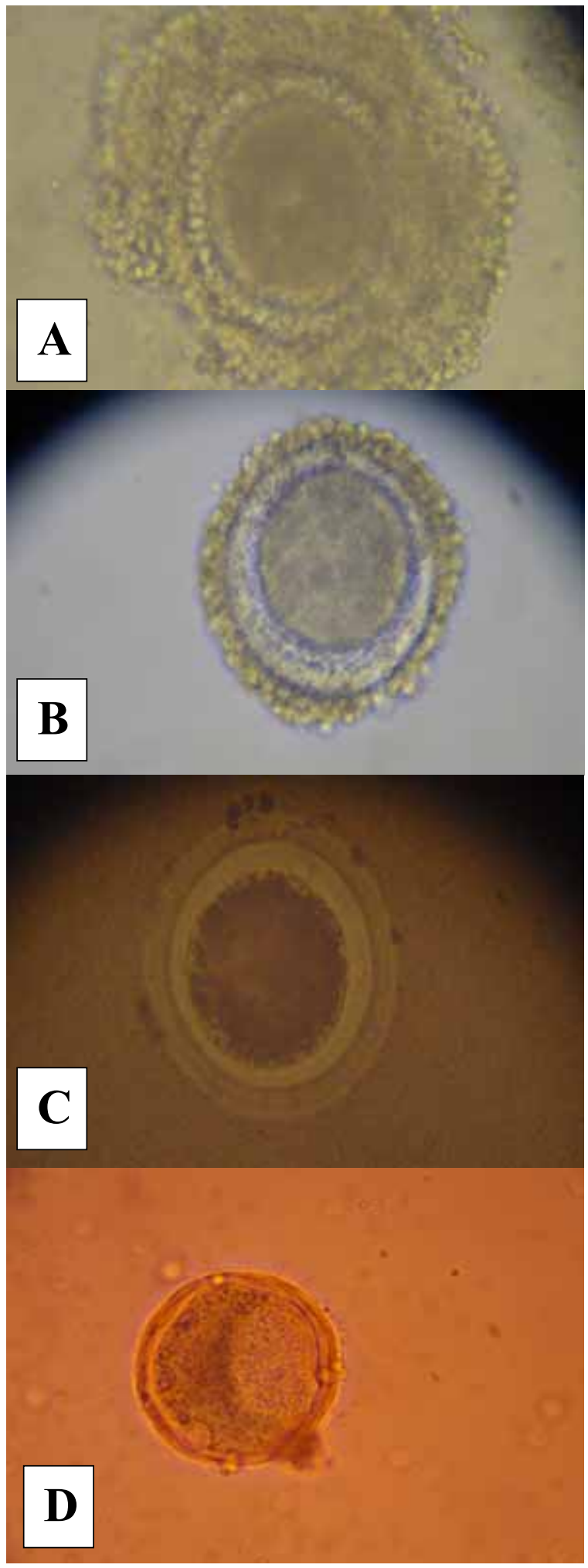

Fig. 5: Different grade bovine Oocytes, A. good ${ }^{+}$grade, B. good $^{-}$grade, C. fair grade D. Poor grade oocyte. 


\section{Oocytes maturation}

Good and fair grade oocytes were only subjected to the process of maturation, maturation medium was prepared as described by (21), mentioned in table 3. Maturation medium was equilibrated for two hours in $\mathrm{CO}_{2}$ incubator before oocytes added; $5-6 \mathrm{ml}$ of the previous medium put in glass petridish then oocytes added later. Medium with oocytes was incubated at $38.5^{\circ} \mathrm{C}$ in $\mathrm{CO}_{2}$ incubator supplied with $5 \% \mathrm{CO}_{2}$ tension and $95 \%$ humidified air for $27-30$ hours (22), matured oocytes were examined under inverted microscope, degree of maturation evaluated as mentioned by (23) depending on the entrance of the matured oocytes to the second metaphase (MII) were assessed and observed by the extruding of the first polar body and the degree of the cumulus oocyte complex expanding in which there were three degrees for assessment of oocytes maturation in regarding to these expanding. Degree2: Cumulus cells were spread homogenously and clustered cells not found. Degree 1: Cumulus cells were spread non- homogenously with presence of clustered cells. Degree 3: Cumulus cells were closely adhering to the zona pellucida without expansion.

According to (14) both degrees 2 and 1 considered as matured oocytes. The graded and selected oocytes were washed more than one time by the same maturation medium; number of matured oocytes were counted and recorded.

\section{Maturation and capacitation of caudal spermatozoa}

Epididymal caudal spermatozoa was prepared by aspiration, as mentioned by (23), 2-3 $\mathrm{ml}$ MEM was loaded in $3 \mathrm{ml}$ plastic syringe connected to 18 gauge needle injected then aspired from the cauda more than one time. The sample was evaluated under light microscope for individual and massive motility, individual motility less than $60 \%$ was rejected. Spermatozoa samples were incubated in $5 \% \mathrm{CO}_{2}$ incubator at $39^{\circ} \mathrm{C}$ for 4 hours for sperm maturation, presence of distal protoplasmic droplet with head to head sperms attachment were regarded as sperm maturation criteria (24). Spermatozoal sample might be subjected to the following process the spermatozoal capacitation in which spermatozoa gained its ability to penetrate the zona pellucida of matured Oocytes for fertilization (IVF). The process was prepared as described by (25), in which 50IU of heparin was added to the matured spermatozoa, and then incubated for 45-60 minutes in $\mathrm{CO}_{2}$ incubator at $39^{\circ} \mathrm{C}$, the plastic syringe contained the later mixture was arranged in the incubator in semi-oblique position.

\section{In vitro fertilization and embryo production}

Capacitated spermatozoa must be examined before mixed and added to the Petridish which contained the matured oocytes, diluted spermatozoa must be prepared to yield 1-2 X $10^{6}$ spermatozoa (26). Gametes mixture was incubated at $5 \% \mathrm{CO}_{2}$ level at $38.5^{\circ} \mathrm{C}$ and $90 \%$ relative humidity for $28-30 \mathrm{hrs}$. Fertilization media supplemented with, LH, FSH, BSA, FCS, antibiotics and antifungal preparation. Developed embryos must be examined and evaluated each $24 \mathrm{hrs}$; embryos showed no progressed signs of development must be discarded, all developed embryos must be evaluated and all results must be recorded.

\section{Results}

\section{Abattoir specimens collection}

The result showed that; it is better to transport the specimens from abattoir to the place of processing directly after slaughter if preserved well by cool box under $4-8^{\circ} \mathrm{C}$, samples yield a questionable decreased ova numbers upon all four collection methods but the degree of ova damaged, aged and deterioration was elevated if the time elapsed from period of slaughter to time of collection until periods of processing at the lab., as shown in table 1.

Table 1: The effect of time elapsed from slaughtering to specimens processing

\begin{tabular}{ccc}
\hline $\begin{array}{c}\text { Time after } \\
\text { slaughter } \\
\text { (Hour) }\end{array}$ & $\begin{array}{c}\text { Ova collection } \\
\text { percentage } \\
\text { (Ova \%)* }\end{array}$ & $\begin{array}{c}\text { Ova quality } \\
\text { deterioration } \\
\text { (Quality parameters)** }\end{array}$ \\
\hline 2 & $75 \%$ & Good + to Good - \\
6 & $68 \%$ & Fair \\
12 & $61 \%$ & Poor \\
24 & $55 \%$ & Aged and Bad
\end{tabular}

*Ova collection percentage for the four collection methods. **Time elapsed after slaughter significantly $(\mathrm{P}<00.5)$ affected ovum quality.

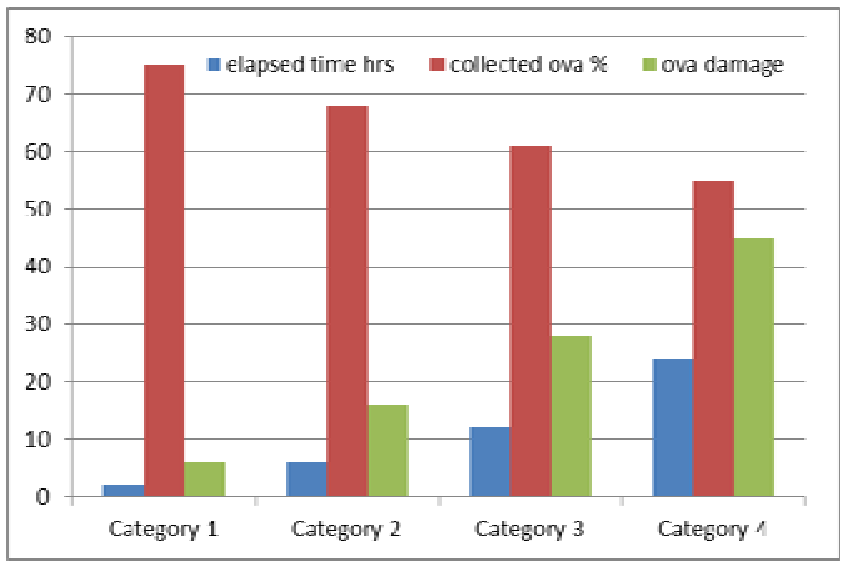

Diagram 1: The effect of time elapsed from slaughtering to specimens processing. 
Effect of abattoir specimens preservative temperature on collected ova quality

The results showed the effect of $\mathrm{s}$ preservative temperature from time of collection to the theriogenology Lab. at the college of Veterinary Medicine in Aljadria state, $4-8^{\circ} \mathrm{C}$, cool box temperature is found to be the more favorable temperature that preserved the specimens until time of processing any changing (rising) in this temperature seriously affects the final result as shown in table 2 and diagram 2.

Table 2: Effect of abattoir specimens preservative temperature on collected ova quality

\begin{tabular}{ccc}
\hline $\begin{array}{c}\text { Preservative } \\
\text { temperature } \\
{ }^{\circ} \mathrm{C}\end{array}$ & $\begin{array}{c}\text { Ova collection } \\
\text { percentage } \\
\text { (Ova \%)* }\end{array}$ & $\begin{array}{c}\text { Ova quality } \\
\text { deterioration } \\
\text { (Quality parameters)** }\end{array}$ \\
\hline $4-8$ & $75 \%$ & Good + to Good - \\
$15-20$ & $68 \%$ & Fair \\
$25-30$ & $61 \%$ & Poor \\
$35-40$ & $55 \%$ & Aged and Bad \\
\hline
\end{tabular}

*Ova collection percentage for the four collection methods.

**Preservative temperature significantly $(\mathrm{P}<00.5)$ affect the ovum quality.

\section{Effect of collecting methods on Oocytes number and grade}

Results showed that the ovarian slicing or chopping method was the method that yield more ova number in regarding to other methods, in which the final result was indicated the ova number for the four method which is aspiration, slashing, slicing after aspiration and the slicing method as 55, 68, 87 and 106 ova respectively. Aspiration method as it yields slightly decreased ova number but it obtained an elevated degree of good evaluated oocytes in regarding to the other method, while slicing one yields an elevated oocytes count but with questionable evaluated degree as recorded in table 3 .

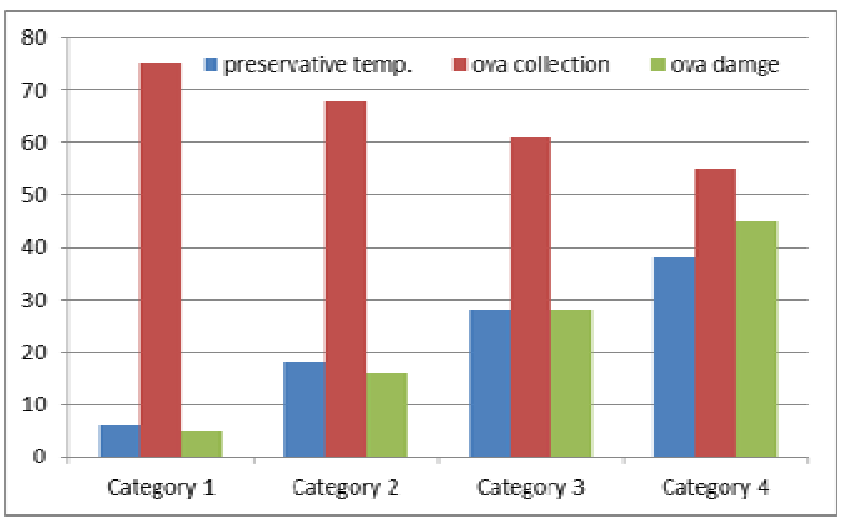

Diagram 2: Effect of preservative temperature on collected ova quality.

\section{Results of degree of maturation and IVF for the good grade oocytes}

Results showed that; time needed for bovine ovum maturation and under a restricted and unchanged incubator interna not less than 28-30 hours, the sign of semi or slight protrusion of ovum membrane outside or even a protrusion and separation of first polar body is the maturation stage accomplishment (fig. 5). The number of oocytes that reached to the maturation stage was listed in table 4 .

\section{Result of aspired caudal spermatozoa maturation and capacitation}

Result showed that; time needed for spermatozoal maturation is the period of re-arrangement, settlement and preparing for the next step which is the capacitation. Incubation for 4 hours $\mathrm{CO}_{2}$ incubator at $39^{\circ} \mathrm{C}$ signs of maturation as distal protoplasmic droplets, aggregation and increased motility were the most signs. Head to head agglutination with more excited flagellar movement were the more distinct capacitation signs.

Table 3: Number of collected and evaluated grade ova in regarding to collection methods

\begin{tabular}{|c|c|c|c|c|}
\hline $\begin{array}{l}\text { Collection } \\
\text { method }\end{array}$ & $\begin{array}{l}\text { No. of collected } \\
\text { ovum }\end{array}$ & $\begin{array}{c}\text { Collected ovum } \\
\%\end{array}$ & Degree of ovum evaluation & $\begin{array}{c}\text { No. of evaluated } \\
\text { ovum }\end{array}$ \\
\hline Aspiration & 55 & 17.4 & $\begin{array}{l}\text { More than } 80 \% \text { of the collected } \\
\text { ova are good grade }\end{array}$ & 44 \\
\hline Slashing & 68 & 21.5 & $\begin{array}{c}\text { More than } 55 \% \text { of the collected } \\
\text { ova are good grade }\end{array}$ & 37 \\
\hline $\begin{array}{l}\text { Slicing after } \\
\text { aspiration }\end{array}$ & 87 & 27.5 & $\begin{array}{c}\text { Less than } 45 \% \text { of the collected } \\
\text { ova are good grade }\end{array}$ & 39 \\
\hline Slicing & 106 & 33.5 & $\begin{array}{c}\text { Less than } 40 \% \text { of the collected } \\
\text { ova are good grade }\end{array}$ & 42 \\
\hline Total number & 316 & 99.9 & & 162 \\
\hline
\end{tabular}


Table 4: Degree of maturation in different collection methods

\begin{tabular}{|c|c|c|c|c|c|c|c|c|c|}
\hline \multirow{2}{*}{$\begin{array}{l}\text { Collection } \\
\text { method }\end{array}$} & \multirow{2}{*}{$\begin{array}{c}\text { No. of evaluated } \\
\text { ovum }\end{array}$} & \multirow{2}{*}{$\begin{array}{c}\text { No. of matured } \\
\text { ovum }\end{array}$} & \multirow{2}{*}{$\begin{array}{c}\text { Maturity } \\
\%\end{array}$} & \multicolumn{6}{|c|}{ Grading * } \\
\hline & & & & $\mathrm{G}$ & $\%$ & $\mathrm{~F}$ & $\%$ & $\mathrm{P}$ & $\%$ \\
\hline Aspiration & 44 & 20 & $45 \%$ & 2 & $60 \%$ & 6 & $30 \%$ & 2 & $10 \%$ \\
\hline Slashing & 37 & 14 & $38 \%$ & 8 & $57 \%$ & 3 & $21.5 \%$ & 3 & $21.5 \%$ \\
\hline $\begin{array}{l}\text { Slicing after } \\
\text { aspiration }\end{array}$ & 39 & 13 & $32 \%$ & 6 & $46 \%$ & 4 & $30.7 \%$ & 3 & $23 \%$ \\
\hline Slicing & 42 & 13 & $31 \%$ & 6 & $46 \%$ & 4 & $30.7 \%$ & 3 & $23 \%$ \\
\hline Total & 162 & 60 & & 32 & & 17 & & 11 & \\
\hline
\end{tabular}

* $\mathrm{G}=$ Good grade, $\mathrm{F}=$ Fair grade, $\mathrm{P}=$ Poor grade.

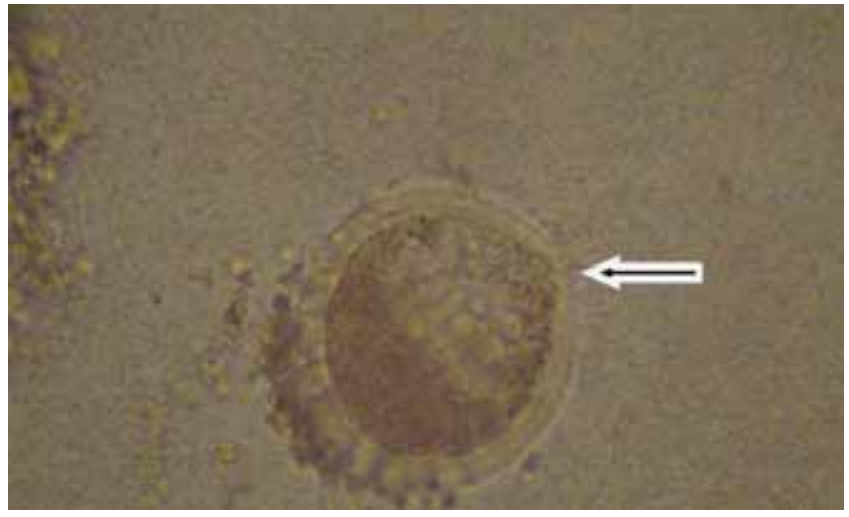

Fig. 6: Matured bovine oocyte an arrow pointed the protrusion of first polar body.

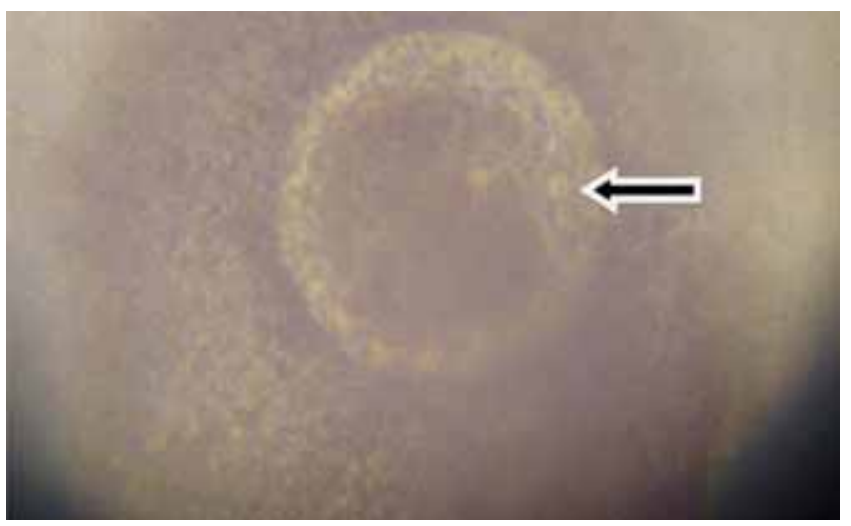

Fig. 7: Matured bovine oocyte where an arrow pointed toward the first polar body.

\section{Results of Invitro fertilization (IVF) and embryo production (IVP)}

Results showed that; time for complete gametes union for zygote development was not less than 28-30 hours; signs as cellular cleavage with second polar body splitting were an indication for IVF and embryos development. Embryonic development and further cleavage were more predominant with the oocytes that obtained from the
Aspiration (8), slashing (4), slicing after aspiration (3) and for slicing was (3), noticed that the only good and fair grade matured oocytes were introduced into the IVF process with abandoned of the poor grade oocytes as discussed in table 5.

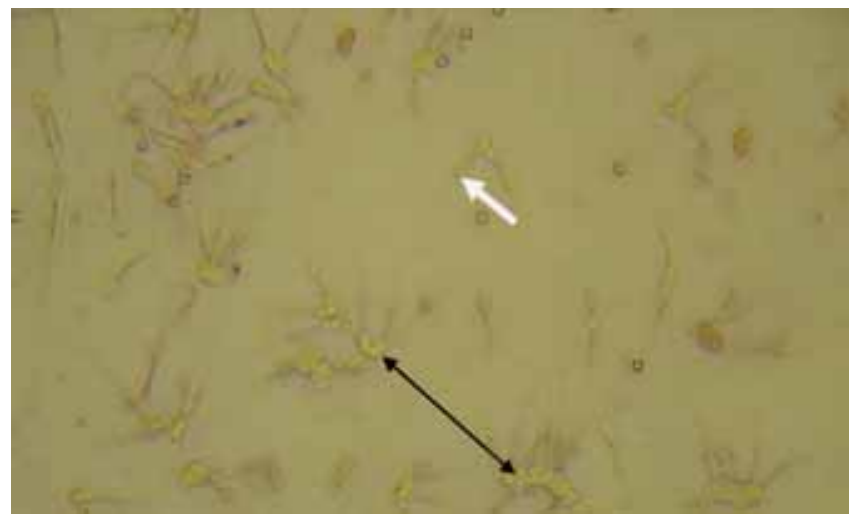

Fig. 8: Maturation of bovine spermatozoa, white arrow pointed toward the droplet, black arrow pointed the spermatozoal aggregation.

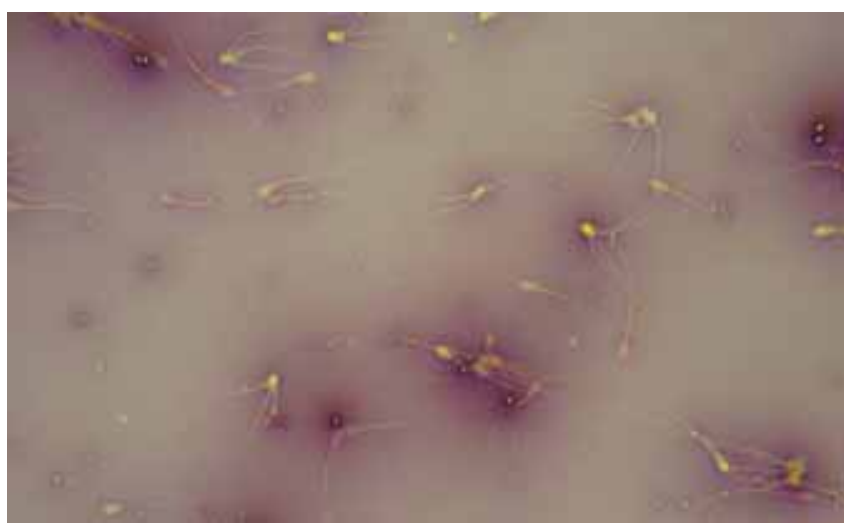

Fig. 9: Capacitated bovine spermatozoa with heparin, notice the flagellum activity with head to head agglutination. 
Table 5: Results and grading of IVF and IVP

\begin{tabular}{lccccccccc}
\hline Collection & Total ova & \multicolumn{4}{c}{ Ovum grading } & \multicolumn{4}{c}{ Embryo development } \\
\cline { 3 - 10 } method & Number & Good & $\%$ & Fair & $\%$ & Good & $\%$ & Fair & $\%$ \\
\hline Aspiration & 18 & 12 & $66 \%$ & 6 & $33 \%$ & 8 & $44.4 \%$ & 2 & $11.1 \%$ \\
Slashing & 11 & 8 & $72 \%$ & 3 & $27 \%$ & 4 & $36.3 \%$ & 3 & $27.2 \%$ \\
Slicing after & 10 & 6 & $60 \%$ & 4 & $40 \%$ & 3 & $30 \%$ & 1 & $10 \%$ \\
aspiration & 10 & 6 & $60 \%$ & 4 & $40 \%$ & 3 & $30 \%$ & 2 & $20 \%$ \\
Slicing & 49 & 32 & $65 \%$ & 17 & $34.6 \%$ & 18 & $36.7 \%$ & 8 & $16.3 \%$ \\
\hline Total & & & & & & & & &
\end{tabular}

Collection method was significantly $(\mathrm{P}<0.005)$ affected the ovum and the developed embryos.

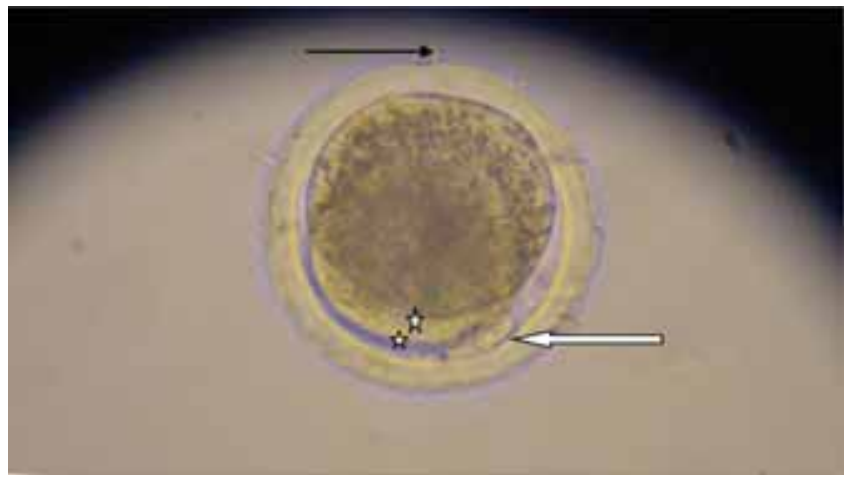

Fig. 10: Two- cells embryo (two white stars) with the $2^{\text {nd }}$ polar body (white arrow) and some of rest of sperm cells (black arrow).

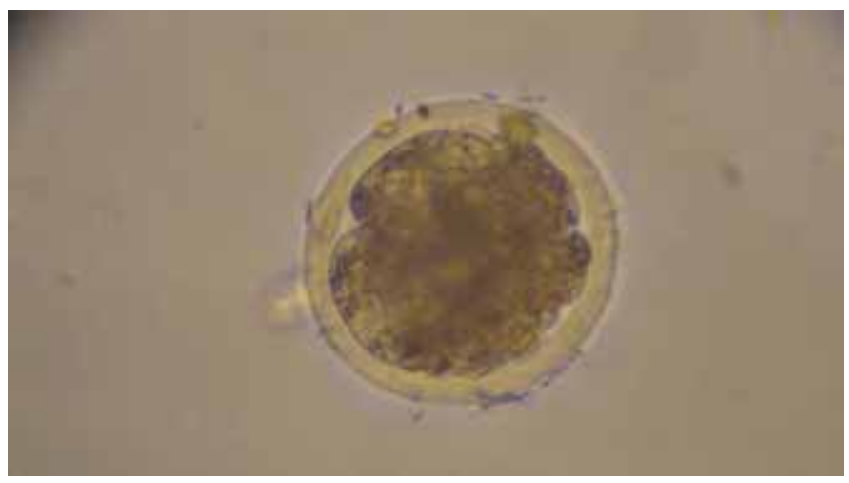

Fig. 11: Four-cell embryo, the four blastomers occupied the whole entire embryo.

\section{Discussion}

The main object of this study is to evaluate the suitable method (s) of bovine oocytes collection from slaughterhouse specimens and the ability of embryos development under all those circumstances that counteractive this opinion which is an important project for obtaining more and more embryos from cheapest and more practical source which is the slaughterhouse specimens and to candidate this as a magnificent method for Assisted Reproductive Technologies (ART).

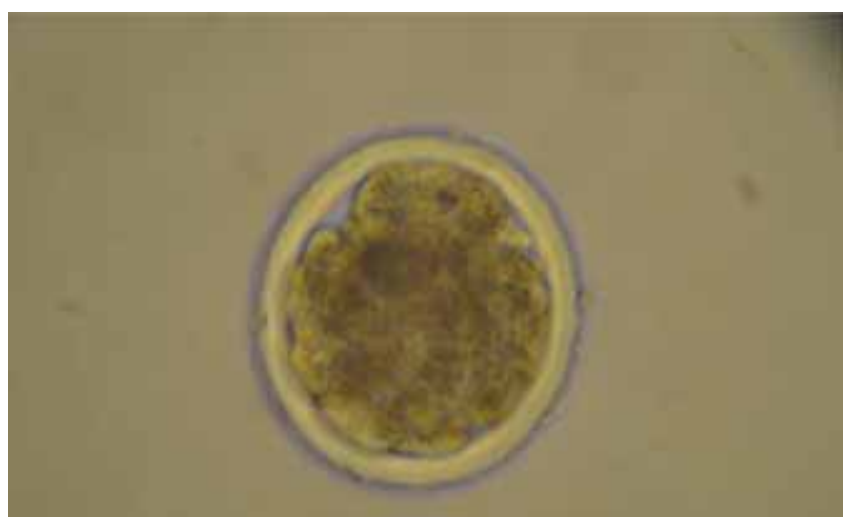

Fig. 12: Multi-cellular embryo 16-32 blastomers.

The effect of elapsed time from slaughter to lab.
processing

Result showed that; there is a direct effect on elapsed time from the period of slaughtering the donor animals toward time of specimens processing inside the Lab., as this time prolonged it affects the oocytes quality which interferes with final result which is the oocytes quality, this result agreed with (27) and this might be due to many factors affect directly the oocytes quality, time of slaughter is the more dominant factor that influence the quality.

(28) approved the effect of elapsed time on the oocytes quality, and that factor might interfere (impaired) with invitro oocytes maturation (IVM) that yield low quality embryos.

\section{The effect of preservative temperature on abattoir specimens}

Abattoir samples must be transported inside container of $4-8^{\circ} \mathrm{C}$ mulluei temperature that preserved the samples from damage or spoilage, this might lead to deterioration of specimens and then bad or aged quality oocytes which interfere with the following step the IVF. (29) mentioned that and agreed in which any elevation over $4-8^{\circ} \mathrm{C}$ might 
affect the process of invitro fertilization or even embryo cleavage later on. (30) approved that; in the processes of IVM, IVF and IVP the main goal is to produce good quality embryos, this is started from the first step which is the specimens (ovaries) transported from the slaughterhouse to the Lab. where all steps are gone. This result was in agreement with the same approval.

\section{The effect of collected method upon oocytes number and quality}

Slicing method and Slicing after aspiration still the predominant methods that yield more and elevated oocytes count $(87,106$ respectively) in regarding to the other two (aspiration, 55 and slashing, 68). The condition that oocyte evaluation and grading are out of comparison, in which, if the oocytes quality after collection need to be counted the arrangement is seem to be started as aspiration, slashing, slicing after aspiration and finally the slicing one $(80 \%$, $55 \%, 45 \%$ and $40 \%$ ) this is true in which, ovaries contain more and more oocytes number but at different stage of maturity, through the process of ovarian chopping for oocytes collection and this gave a chance for all Oocytes to be matured with different degree. (31) observed this when compared with many collection methods of bovine oocytes, the slicing method yield more oocytes count than the other methods. (32) agreed with this in which, the recovery of oocytes by the slicing method is simple and efficient compared with the aspiration and puncturing methods. (3) approved that; slicing technique recovered more oocytes per ovary (2.4 times) than that of aspiration and the best maturation rate was observed from oocytes obtained by this method which are surrounded by more than 3 layers of cumulus cells.

(33) agreed with our study that slicing method is superior as compared with the other methods employed in his study that obtained the ability to harvest a greater number of good quality as well as culture grade Oocytes.

(16) was disagreed that the slicing method is not the method to be choose if compared with the other methods in regarding to the more debris and tissues remnant as well as more immature oocytes with low quality grading are obtained while the aspiration method, even it gives low oocytes number but with good quality and less tissues debris.

\section{Effect of invitro maturation (IVM) upon oocytes collection}

Results showed that; bovine oocytes maturation time is about 28-30hrs., which is correlated to the collection method in which the aspiration method yield a less oocytes count but with a predominant degree of maturation in regarding to other methods. (34) observed that; when trying to compare between different methods for oocytes collection in regarding to the Oocytes number, quality and degree of maturation, the slicing and slicing after aspiration methods came in earlier methods that yield more Oocytes count with good quality that reached to maturity condition in well considered degree. In present study we conclude that; kind of bovine oocytes collection from abattoir ovarian specimens may have an effect on oocytes count as well as maturation. Previous investigation by (35) showed there was a slight effect or even no effect of the oocytes collection methods upon oocytes maturation which was mainly related to the incubated medium with hormones, proteins or else. (36) in cattle also showed that the recovery method by aspiration or surface dissection did not have a significant effect on cleavage rate or blastocyst yield after IVP procedure. Similar results were obtained in goats, in which no significant differences were seen in the subsequent percentages of oocytes maturing, being fertilized and developing in vitro among the slicing and aspiration methods of recovering oocytes $(32,37)$.

\section{Effect of spermatozoal maturation and capacitation on IVF}

Results of this study conclude that; maturation of spermatozoa by incubation in $\mathrm{CO} 2$ incubator for $4 \mathrm{hrs}$ followed by $45-1 \mathrm{hr}$ capacitation is needed for complete IVF process. Previous study by (38) showed that, the sperm treatment itself did not influence the IVF process, like in goat; different semen preparation techniques did not affect the penetration and cleavage rates of oocytes. (25) approved that; heparin was capable of increasing the ability of bovine sperm to fertilize matured bovine oocytes in vitro. In previous study by (39), they concluded that; process of spermatozoa capacitation is an important event that gains the spermatozoa the ability to penetrate the zona pellucida of matured oocyte, in which seminal plasma contains positive and negative regulatory elements which are responsible for reconstituting activity of spermatozoa, negative regulatory elements that inhibit the spermatozoal activity are inactivated during sperm capacitation, permitting the expression of positive regulators which act together to gain the zona penetration by spermatozoa.

(40) agree that; capacitation is a key process through which spermatozoa acquire their fertilizing ability and this event is required for the successful application of assisted reproductive technologies such as IVF.

(41) found that effect of the glycosaminoglycan or the heparin with its concentrations on the modulation improvement of the sperm activity to hyperactivity in connection with $\mathrm{Ca}^{+2}$ ions (capacitation), concentrations of heparin significantly affected the capacitation final results.

\section{Results of IVF and IVP}

Capacitated spermatozoa when added in adequate concentration to the dish contained matured oocytes can be able to penetrate the zona pellucida, time recorded by this 
study for complete gametes union, cleavage and embryo development was 28-30hrs. (42) in his previous study approved that, matured bovine oocytes when incubated with capacitated bull spermatozoa has the ability to undergo cleavage and developed zygotes that continued to term of embryos development.

(43) approved that; the penetration of matured-oocyte zona pellucida by capacitated spermatozoa activated the cleavage and embryo development but at period of $24 \mathrm{hrs}$ incubation.

(44) in previous study approved that; cleavage of oocytes activated by capacitated spermatozoal penetration; cleavage percentage might be up to $60 \%$ when incubated with suitable condition and time.

(12) in their study approved that the oocytes quality significantly affect the IVF final result, and this might be related to lesser number of zygotes development especially that with the slicing after aspiration or with the slicing methods.

Blondin, (45) demonstrated the important of the IVF in the technology of the embryo transfer, this process if manipulated well could be act as an improvement tool in bovine industry when all facilities were prepared well.

(46) on his study concluded that; season did not have any apparent effects on the quality of collected oocytes or even the further IVM process or IVF results, this fact was not involved in our study, because our specimens include in this study are abattoir specimens and these specimens have no previous history before slaughter, unless; (47) on another study concerning factors that influence the final result of IVF and its relation with the IVP, he found that body condition might influence the oocytes quality but be with no effect (significantly) upon final result or zygotes development, the season has a degree of effect upon IVF and zygotes cleavage, he concluded that Autumn period was the more favorable time for embryos production, and this was one of the reason that why we collected less embryos?, this might be to the season that our study started with, which is the Winter season.

(48) approved that; donor animal body condition (body condition score BCS) affect the collected oocytes quality which in turned affected the IVF and the embryos yield quality, this was agree with the same previous results and may affects the final results of this study in which no history for donors cow.

(49) in his study found that; the success of IVF of bovine matured oocytes after union with capacitated spermatozoa was estimated $48 \mathrm{hrs}$, while the identification of male and female pronucleus might be visible after 18$22 \mathrm{hrs}$ following this co-incubation and fertilization, in which time mentioned by this study for complete cleavage and 2-4 cell embryo development was about 28-30hrs and this might be related to the degree of collected oocytes quality and grade of maturation.

\section{Conclusion and recommendations}

It was concluded from this study that the slaughterhouse specimens was the suitable and cheapest source for bovine oocytes. Slicing the cow ovaries method for oocytes collection yield more oocytes count with moderate quality while aspiration method yields less oocytes number with good quality. It was the wright thing not to discard the ovarian samples after aspiration in which they still gain more oocytes that can obtained by slicing those ovaries. Slashing method for oocytes collection was better with less debris and cellular tissues remnant that made the inspection for oocytes so easy. Time consuming for specimens transport as well as the temperature of transporting vessel affect the samples quality. We recommend using slaughterhouser specimens and slicing method for obtaining more oocytes numbers.

\section{References}

1. Suhail SMIR, Lone FA, Khan MZ, Malik AA, Islam R, Sofi KA. Effect of cold storage period on the quality of ram cauda epididymal spermatozoa recovered postmortem. Turk J Vet Anim Sci. 2012;36(6):683-687.

2. Suresh KP, Nandi S, Mondal S. Factors affecting laboratory production of buffalo embryos:A meta-analysis. Theriogenol. 2009;2:978-985

3. Sianturi RG, Thein M, Wahed H, Rosnina Y. Effect of collection technique on yield of bovine oocytes and the development potential of oocytes from different grades of oocytes. JITV. 2002;7(3):188-193.

4. Gautam Deb, Dey SR, Nahar TN, Rahman MM. In vitro production of bovine blastocyst with oocyte collected from abattoir ovary. Bangladesh J Anim Sci. 2016;45(1):31-35.

5. Mohammed and Hatif. Bovine oocyte maturation collected from abattoir and in vitro fertilization. Al-Anbar J Vet Sci. 2010;3(2):201.

6. Masudul HSA, Sanjoy KK, Yahia KAM, Anupom M, Tareq KMA. Effect of collection techniques on cumulus oocyte complexes (COCs) recovery, in vitro maturation and fertilization of goat Oocytes. Afri J Biotechnol. 2011;10(45):9177-9181.

7. Rehman MGM, Goswami PC, Yahia K, Tareq MAM, Ali SZ. Collection of bovine cumulus-oocyte-complex (COCs) from slaughterhouse ovaries in Bangladesh. Pakistan J Biolog Sci. 2003;6 (24):2054-2057.

8. Cognié Y, Baril G, Poulin N, Mermillod P. Current status of embryo technologies in sheep and goat. Theriogenol. 2003;59:171-188.

9. Gianluca N, Bianca G, Viviana CB, Rossella DP, Giuseppe C, Giorgio AP, Luigi Z. Bovine and Buffalo in vitro embryo production using Oocytes derived from abattoir ovaries or collected by transvaginal follicles aspiration. Adv Res. 2003;59(5-6):1123-1130.

10. Jamil H, Samad HA, Qureshi ZI, Rehman NU, Ladhi LA. Harvesting and evaluation of riverine buffalo follicular oocytes. Turk J Vet Anim Sci. 2008;32:25-30.

11. Hamed KS, Mohammad HS, Hadi H, Gholamali M. In vitro developmental competence of bovine oocytes: Effect of corpus luteum and follicle size. Iran J Reprod Med. 2015;13(10):615-622.

12. Bilodeau-Goeseels S, Panich P. Effect of oocytes quality on development and transcriptional activity in early bovine embryos. Anim Reprod Sci. 2002;17:71(3-4):143-155.

13. Wang ZG, Xu ZR, Yu SD. Effects of oocyte collection techniques and maturation media on in vitro maturation and subsequent embryo development in Boer goat. Czech J Anim Sci. 2007;52(1):21-25.

14. Saleh WM. Role of Epididymal Spermatozoa In Vitro Fertilization and Embryo transfer in Iraqi Sheep. Thesis submitted to the Council 
of the collage of vet. medicine, University of Baghdad in partial fulfillment of the requirement for the degree of doctor of Philosophy in Vet. Med./Theriogenol. 2016.

15. Sofi KA, Khan MZ, Akhoon ZA, Lone FA, Wani AR. In vitro maturation of Oocytes in sheep: An Overview. Indian J Small Rumin. 2012;18(1):16-25.

16. Beenish S, Samina J, Muhammad IK, Sajjad AS. Different methods of Oocytes recovery for in vitro maturation in Nili Ravi ubffalo's Oocytes. Apcbee Procedia. 2014;8:359-363.

17. Luis AD, Peter H. Slashing technique for bovine Oocytes recovery. University of Florida. www.youtube.com/watch?v=Rfi80TUjbG4. 2009

18. Abid M, Muhammad A, Sayed M, Muhammad A, Syed M. In vitro maturation and fertilization of buffalo oocytes:the effect of recovery and maturation methods. Turk J Vet Anim Sci. 2011;35(6):381-386.

19. Suresh K, Maurya SN. Evaluation of oocyte retrieval methods from bubaline ovaries Indian J Anim Res. 2000;34(2):130-132.

20. Rahman ANMA, Abdullah RB, Wan-Khadijah WE. Review Article; In vitro maturation of oocytes with Special Reference to Goat: A Review. Biotechnol. 2008;7:599-611.

21. Wani AR, Khan MZ, Sofi KA, Malik AA, Lones FA, Bhat FA. Effect of follicular size on in vitro maturation, fertilization and culture of sheep embryos. Iranian J Vety Res. 2013;14(4):299-304.

22. Maria IK, Georgi D. Influence of selected seminal plasma proteins in mitochondria integrity and speed parameters of ram spermatozoa stored at low temperature. Biotec Biotechnol. 2011;25(4):2591-2596.

23. Bertol MA, Weiss F, Thomaz-Soccol RR, Kozicki V, Fujita, de Abreu AS, Green KT. Viability of bull spermatozoa collected from the epididymis stored at $18-20^{\circ} \mathrm{C}$. Braz Arch Biol Technol. 2013;56(5):777-783.

24. Lone FA, Islam R, Khan MZ, Sofi KA. Effect of collection methods on the quality and quantity of spermatozoa recovered from the epididymis of slaughtered ram. Indian Vet J. 2011;88:46.

25. Parrish JJ. Bovine in vitro fertilization:In vitro oocyte maturation and sperm capacitation with heparin. Theriogenol. 2014;(1):81:67-73.

26. Hernández P, Ortiz JE, Rodríguez F , Ducolomb JL, Reyes Y, Betancourt F, Casas M, Heuze E, Kjelland Y, Romo S. Use of IVF and ET in Mexican Criollo Sheep (Ovis aries): Immediate and delayed embryo transfer. Adv Reprod Sci. 2016;4:8-16.

27. Lonergan P, Fair T. Maturation of Oocytes in Vitro. Annual Rev Ani Biosci. 2016;4:255-268.

28. Lihua Lv, WenbinYue, Wenzhong Liu, Youshe Ren, Fuzhong Li, Kyung-Bon L. Effect of oocyte selection, estradiol and antioxidant treatment on in vitro maturation of oocytes collected from prepubertal Boer goat. Italian J Ani Sci. 2010;9(1):334-342.

29. Blad-Stahl N, Kotarski F, Wrenzyck C. Liquid preservation of bovine embryos as an alternative to cryopreservation. Proceedings of the 30th Annual Meeting of the Brazilian Embryo Technology Society (SBTE); Brazil, August 25th to 27th, 2016, and 32nd Meeting of the European Embryo Transfer Association (AETE); Barcelona, Spain. 2016.

30. Nikdel K, Ghanem K, Khajenabi N, Kamaledini M, MohammadiSangcheshme R. Royal jelly improves embryonic developmental competence and affects transcript levels of apoptosis-related genes in goat cumulus-oocyte complexes. Proceedings of the 30th Annual Meeting of the Brazilian Embryo Technology Society (SBTE); Brazil, August 25th to 27th, 2016, and 32nd Meeting of the European Embryo Transfer Association (AETE); Barcelona, Spain. 2016.

31. Wang Z, Song-dong Yu, Zi-rong X. Effects of collection methods on recovery efficiency, maturation rate and subsequent embryonic developmental competence of Oocytes in Holstein cow. Asian Aust J Anim Sci. 2007;20(4):496-500.

32. Pawshe CH, Totey SM, Jain SK. A comparison of three methods of recovery of goat oocytes for in vitro maturation and fertilization. Theriogenol. 1994;42 (1):117-25.

33. Mutha RM, Uma MY. Efficacy of different harvesting techniques on oocyte retrieval from buffalo ovaries. Buffalo Bull. 2012;31(4):209213.

34. Hammad ME, Gabr ShA, El-Ratel IT, Maha AG. Efficacy of different collection techniques on yield and quality of Egyptian buffalo oocytes. J Anim Poul Prod. 2014;5(7):413-422.

35. Hannelore A, Helmut T, Wilhelm K, Knut R. Influence of oocyte recovery method, in vitro fertilization method and serum source on embryonic development of in vitro matured bovine oocytes. Arch Tierz Dummerstorf. 2008;51(3):224-234.

36. Carolan C, Monaghan P, Gallagher M, Gordon I. Effect of recovery method on yield of bovine oocytes per ovary and their developmental competence after maturation, fertilization and culture in vitro. Theriogenol. 1994;41:1061-1068.

37. Martino A, Palomo MJ, Mogas T, Paramio MT. Fertilization. Theriogenol. 1994;42:859-873.

38. Palomo MJ, Izquierdo D, Mogas T, Paramio MT. Effect of semen preparation on IVF of prepubertal goat Oocytes. Theriogenol. 1999;51(5):927-940.

39. Florman HM, First NL. Regulation of acrosomal exocytosis. II. The zona pellucida-induced acrosome reaction of bovine spermatozoa is controlled by extrinsic positive regulatory elements. Dev Biol. 1988;128(2):464-473.

40. García-Álvarez O, Maroto-Morales A, Jiménez-Rabadán P, Ramón M, del Olmo E, Iniesta-Cuerda M, Anel-López L, Fernández-Santos MR, Garde JJ. Soler AJ. Effect of different media additives on capacitation of frozen-thawed ram spermatozoa as a potential replacement for estrous sheep serum. Theriogenol. 2015;84(6):948955.

41. El-Shahat KH, Taysser MI, Badr MR, d Zaki KA. Effect of heparin, caffeine and calcium ionophore A23187 on in vitro induction of the acrosome reaction of fresh ram spermatozoa. Asian Pacific J Reprod. 2016;5(2):148-155.

42. Rehman NU, Sarwar M, Samad HA. In vitro Production of bovine embryo- A review. Asian- Aust. J Anim Sci. 2001;14(9):1342-1351

43. Chian RC, Niwa K, Nakahara H. Effect of sperm penetration in vitro on completion of first meiosis by bovine oocytes arrested at various stages in culture. J Reprod Fert. 1992;96:73-78.

44. Greve T, Madiso V. In vitro fertilization in cattle: A review. Reprod Nutr Dev. 1991;3:147-157.

45. Blondin P. Status of embryo production in the world. Anim Reprod. 2015;12(3):356-358.

46. Takuma T, Sakai S, Ezoe D, Ichimaru H, Jinnouchi T, Kaedei Y, Nagai $T$, Otoi $T$. Effects of season and reproductive phase on the quality, quantity and developmental competence of oocytes aspirated from Japanese black cows. J Reprod Develop. 2010;56(1):55-59.

47. Peter C, Elena K, Lucia O, Alexander VM. Effect of body condition and season on yield and quality of in vitro produced bovine embryos. Zygote. 2015;23(6):893-899.

48. Kubovičová E, Makarevich AV, Hegeduesova Z, Slezakova M, Bezdicek J. Effect of body condition score on oocytes yield and in vitro embryo development. Home-page AGRIS. 2012.

49. Marko S, Iva Getz, Martina L, Hrvoje V, Drazen D. Optimization of sperm for in vitro production of bovine embryos. SOJ Vet Sci. 2015;1(2):1-7. 